\title{
PENGARUH KECERDASAN EMOSIONAL DAN PEMBERDAYAAN KARYAWAN TERHADAP KOMITMEN ORGANISASIONAL MELALUI KEPUASAN KERJA DI DINAS SOSIAL DAERAH ISTIMEWA YOGYAKARTA
}

\author{
Nur Arifan ${ }^{1}$, Fereshti Nurdiana Dihan ${ }^{2}$ \\ ${ }^{1}$ Universitas Islam Indonesia Yogyakarta \\ ${ }^{2}$ Universitas Islam Indonesia Yogyakarta \\ fereshtideevadha@gmail.com
}

\begin{abstract}
The research was purposed to find out whether there was any significant of emotional intelligence and employee empowerment to organizational commitment through job satisfaction on Social Service in Special Region of Yogyakarta. The participants of this research are the employees of Social Service in Special Region of Yogyakarta. Quantitative approach was used during data collection which 107 employees had been participated. This study was using SmartPLS 3.0 version to test the hypothesis.

The results of this study found that there are significant positive effect of emotional intelligence on organizational commitment, significant positive effect of employee's empowerment on organizational commitment, significant positive effect of emotional intelligence on job satisfaction, and significant positive effect of organizational commitment on job satisfaction, also there is significant positive effect of job satisfaction on organizational commitment. In addition, this study found the direct influence of emotional intelligence on organizational commitment is greater than indirect influence of emotional intelligence on organizational commitment through job satisfaction, and the direct influence of employee empowerment on organizational commitment is greater than indirect influence of employee empowerment on organizational commitment through job satisfaction.
\end{abstract}

Kata kunci : Emotional Intelligence, Employee Empowerment, Organizational Commitment, Job Satisfaction.

() 2018 JBTI. All rights reserved

Article history : received 28 Agt 2018; revised 21 Sep 2018; accepted $20 \mathrm{kt} 2018$

\section{PENDAHULUAN}

Salah satu komponen penting dalam sebuah organisasi adalah sumber daya manusia yang ada di dalamnya. Mathis \& Jackson (2011), menyatakan bahwa sumber daya manusia merupakan bagian khsusus yang di miliki dari setiap organisasi, yang artinya organisasi harus mampu melihat bakat seorang karyawan untuk meningkatkan kinerja karyawan dan sebagai kesempatan untuk menciptakan keunggulan kompetitif organisasi yang lebih besar. Selain itu, Bohlander \& Snell (2010), menyatakan bahwa sumber daya manusia merupakan kemampuan yang terintegrasi dari daya fikir dan daya fisik yang dimiliki setiap individu yang dibangun agar mampu bersaing dalam menghadapi persaingan yang semakin ketat. Dengan kompetensi dan kualitas tinggi yang dimiliki, muncul berbagai permasalahan didalam organisasi yang berkaitan dengan bagaimana organisasi mampu mempertahankan karyawan dengan komitmen yang tinggi terhadap organisasi. Seperti teori yang diungkapkan oleh Abraham Maslow yang mengemukakan ada 5 jenis kebutuhan yang harus dipenuhi seorang karyawan dalam organisasi, yaitu: 1) 
kebutuhan dasar; 2) kebutuhan rasa aman; 3) kebutuhan berafiliasi; 4) kebutuhan harga diri; 5) kebutuhan aktualisasi diri, (Rivai, 2009).

Komitmen organisasional secara umum diartikan sebagai identifikasi dan keterlibatan dari seseorang yang relatif kuat terhadap suatu organisasi. Sementara Robbins (2006), mengatakan bahwa komitmen organisasional sebagai suatu sikap dimana karyawan dapat merefleksikan perasaan suka atau tidak suka terhadap organisasi. Sampai saat ini, komitmen organisasionalonal masih terus dipelajari dan masih menjadi obyek penelitian yang menarik untuk diteliti khususnya dalam bidang SDM dan perilaku organisasi. Komitmen organiasasi sudah banyak dikaitkan dengan beberapa variabel penelitian oleh para peneliti, seperti dengan variabel komitmen profesional, organizational citizenship behavior (Bogler \& Somech, 2004), kepuasan kerja, keadilan organisasional (Karim \& Rehman, 2012; Tjahjono, 2008; Tjahjono et al., 2015), perilaku disfungsional (Palupi \& Tjahjono, 2016), Teamwork, Employee Training (Hanaysha, 2016), dan occupational stress (Aghdasi Kiamanesh \& Ebrahim, 2011). Oleh karena itu, untuk meningkatkan komitmen organisasional para karyawan, terdapat beberapa faktor yang mempengaruhinya seperti kecerdasan emosional yang dimiliki oleh karyawan, pemberdayaan karyawan yang diberikan oleh organisasi, dan kepuasan kerja karyawan pada pekerjaan yang dilakukan.

Faktor pertama yang mempengaruhi komitmen organisasional adalah kecerdasan emosional. Goleman (dalam Armstrong \& Taylor, 2014) mendefinisikan kecerdasan emosional sebagai kapasitas untuk mengenali perasaan sendiri dan perasaan terhadap orang lain, untuk memotivasi diri dan mengolah emosi diri sendiri dalam hubungannya dnegan orang lain. Lebih lanjut Goleman (2003), mengungkapkan bahwa kecerdasan emosional memiliki keampuhan yang sama dengan kecerdasasn intelektual, dan terkadang lembih ampuh dari kecerdasan intelektual, hal ini dipertegas bahwa kecerdasan intelektual hanya menyumbang $20 \%$ bagi kesuksesan seseorang, sementara $80 \%$ lainnya ditentukan faktor lain, maka tidak dapat dipungkuri bahwa kecerdasan emosional sangat penting dan mampu mempengaruhi komitmen organisasional karyawan. Hal ini didukung oleh penelitian yang dilakukan Karambut dan Noormijati (2012), mengungkapkan bahwa melalui kecerdasan emosional, seseorang akan belajar mengelola perasaannya sehingga dapat mengekspresikannya secara tepat dan efektif.

Faktor kedua yang mempengaruhi komitmen organisasional adalah pemberdayan karyawan. Herzberg, et al (1959), menayatakan pemberdayaan karyawan merupakan sebuah otonomi kerja dan pengkayaan yang difokuskan pada peningkatan pengendalian dan pengambilan keputusan dalam pekerjaan seseorang. Sementara, Yulk dalam Supriyanto (2009), menyatakan bahwa pemberdayaan karyawan merupakan motivasi intrinsik dan self-efficacy dari orang yang terpengaruh oleh perilaku kepemimpinan, karakteristik pekerjaan, struktur organisasi, dan kebutuhan serta nilai-nilai mereka sendiri. Ini sesuai dengan hasil penelitian yang dilakukan oleh Jafari et al (2013), yang mengungkapkan bahwa pemberdayaan karyawan enjadi sesuatu hal penting karena didalam mengahadapi era persaingan dan pelayanan, setiap organisasi membutuhkan karyawan yang cepat tanggap dan mandiri sehingga organisasi mempunyai keunggulan kompetitif melalui sumber daya manusia.

Faktor ketiga yang mempengaruhi komitmen organisasional adalah kepuasan kerja. Armstrong dan Taylor (2014), menyatakan bahwa kepuasan kerja sebagai perilaku dan perasaan seseorang terhadap pekerjaan yang mereka miliki. Dengan begitu produktivitas karyawan dapat ditingkatkan dengan membuat karyawan dalam organisasi merasa lebih puas, karena diberdayakan oleh organisasi dan kebutuhan sosial dari seorang karyawan merasa terpenuhi. Dengan demikian, karyawan yang memiliki tingkat kepuasan kerja yang tinggi, seorang karyawan akan menunjukkan perhatian yang tinggi terhadap organisasi yaitu dengan tetap ingin bertahan didalam organisasi. Ini sesuai dengan penelitian yang dilakukan oleh Gangai dan Agrawal (2015), yang menemukan bahwa kepuasan kerja dapat meningkatkan komitmen terhadap organisasi. 
Tujuan dari penelitian ini adalah untuk mengetahui hubungan antara kecerdasan emosional dan pemberdayaan karyawan terhadap komitmen organisasional dan kepuasan kerja. Penelitian ini unik karena mencoba untuk menganalisis keempat variabel (kecerdasan emosional, pemberdayaan karyawan, komitmen organisasional, kepuasan kerja) dalam satu model penelitian. Penelitian ini juga unik karena memasukkan variabel pemberdayaan karyawan kedalam model penelitian. Karena, pemberdayaan karyawan masih jarang dalam penelitian penelitian terdahulu.

\section{KAJIAN TEORI}

\section{a. Kecerdasan Emosional}

Goleman (1990), mendefinisikan bahwa kecerdasan emosional sebagai kemampuan dalam mengenali perasaan diri sendiri dan perasaan orang lain, dalam memotivasi diri sendiri dan mengelola emosi dengan baik terhadap diri sendiri maupun dalam hubungan yang berkaitan dengan diri sendiri. Sedangkan menurut Davies dalam Auda (2016), menyatakan definisi kecerdasan emosional sebagai kemampuan yang baik dalam memahami emosi dalam diri sendiri dan membaca emosi orang lain. Mayer (1990), dalam Goleman (2007), mengungkapkan bahwa terdapat dua sisi dari kecerdasan emosi, yaitu yang pertama adalah kepandaian dalam memahami emosional serta menambahkan kreativitas, dan yang kedua intuisi yang ada pada pikiran logis. Secara umum Goleman (2003), menjelaskan bahwa terdapat lima kerangka kerja utama pada kecerdasan emosional yaitu: pertama, Self awareness merupakan kemampuan untuk mengatahui apa yang dirasakan dalam dirinya dan menggunakannya untuk menuntun dalam pengambilan keputusan diri sendiri, serta memiliki tolok ukur yang realitstis atas kemampuan yang dimiliki oleh diri sendiri, dan kepercayaan diri yang sangat kuat. Kedua, Self regulation merupakan kemampuan seseorang dalam mengendalikan serta menangani emosinya sendiri, sedemikian rupa sehingga akan berdampak positif pada pelaksanaan tugas yang dilakukan, memiliki kepekaan pada kata hati, dan sanggup untuk menunda kenikmatan sebelum sasaran yang direncanakan tercapai, serta dapat kembali pulih dari tekanan emosi yang terjadi. Ketiga, Self motivation merupakan hasrat yang dimiliki seseorang yang paling dalam untuk menggerakkan dan menuntun diri menuju suatu sasaran, membantu dalam pengambilan inisiatif, serta bertindak dengan seefektif mungkin, dan mampu untuk bertahan juga bangkit dari kegagalan dan frustasi yang dialami. Keempat, Empathy merupakan kemampuan yang dimiliki seseorang dalam proses merasakan apa yang dirasakan oleh orang lain, mampu dalam memahami perspektif orang lain dan mampu menumbuhkan hubungan rasa saling percaya satu sama lain, serta mampu menyelaraskan diri dengan berbagai tipe hubungan. Kelima, Social skill merupakan kemampuan untuk menangani emosi dengan baik ketika berhubungan sosial dengan orang lain, mampu membaca situasi dan jaringan sosial secara cermat, berinteraksi dengan lancar, menggunakan ketarampilan untuk mempengaruhi orang lain, memimpin, bermusyawarah, menyelesaikan perselisihan, serta bekerjasama dalam tim.

\section{b. Pemberdayaan Karyawan}

Snell and Bohlander (2013), mengungkapkan bahwa pemberdayaan merupakan proses pemberian kekuatan kepada karyawan untuk dapat menginisiasi perubahan, dengan demikian akan dapat mendorong mereka untuk mengambil tanggungjawab atas apa yang mereka lakukan. Pemberdayaan karyawan kini merupakan tren pengelolaan modal manusia di dalam organisasi di masa depan (Mulyadi, 2007). Lebih lanjut Herzberg, et al (1959), menyatakan pemberdayaan karyawan merupakan sebuah otonomi kerja dan pengkayaan yang difokuskan pada peningkatan pengendalian dan pengambilan keputusan dalam pekerjaan seseorang. Spreitzer (1995), menyatakan bahwa konsep pemberdayaan ini direfleksikan dalam empat dimensi, yaitu: pertama, Meaning, mengacu pada sejauh mana seorang karyawan memiliki rasa tujuan atau hubungan pribadi tentang pekerjaannya. Kedua, Competence, mengacu pada sejauh mana seorang 
karyawan percaya bahwa dirinya memiliki keterampilan dan kemampuan yang diperlukan untuk melakukan pekerjaan mereka dengan baik. Ketiga, Self-determination, mengacu pada sejauh mana seorang karyawan memiliki rasa kebebasan tentang bagaimana individu melakukan pekerjaannya di dalam perusahaan. Keempat, Impact, mengacu pada sejauh mana seorang karyawan percaya bahwa dirinya dapat mempengaruhi sistem organisasi atau perusahaan dimana dia bekerja.

\section{c. Komitmen Organisasional}

Menurut Robbins (2006), komitmen organiasi adalah suatu keadaan dimana seorang karyawan akan memihak kepada organisasi tertentu dan memiliki tujuan serta keinginan untuk tetap bertahan menjadi anggota dalam organisasi tersebut. Sementara, menurut Porter et al., (1974), mendefinisikan komitmen organisasional adalah keinginan untuk tetap bergantung pada nilai organisasi, berupaya untuk mengikuti nilai tersebut, dan keinginan untuk selalu menjadi bagian dari organisasi. Menurut Luthan (2006), komitmen organisasional memiliki sifat multidimensional, oleh karena itu terdapat perkembangan dukungan terhadap tiga dimensi dalam komitmen organisasional yang telah diterangkan dalam literature Allen dan Meyer (1997). Dimensi yang dimaksud adalah sebagai berikut: pertama, Komitmen afektif (affective commitment), merupakan pendekatan atau keterikatan emosional dari individu dalam keterlibatannya dengan organisasi, sehingga individu tersebut akan merasa dihubungkan dengan organisasi. Dalam komitmen afektif seorang individu ingin menetap dalam organisasi dikarenakan keinginannya sendiri. Komponen afektif memiliki kaitan dengan emosional, indetifikasi serta keterlibatan seorang karyawan dalam suatu organisasi. Kedua, Komitmen kontinuan (continuance commitment), merupakan rasa atau hasrat yang dimiliki seorang individu untuk bertahan di dalam organisasi, sehingga individu tersebut akan merasa perlu untuk dihubungkan dengan organisasi. Komitmen kontinuan ini akan didasarkan pada persepsi para pegawai tentang seperti apa kerugian yang akan diterima jika mereka meninggalkan organisasi tersebut. Ketiga, Komitmen normatif (normative commitment) merupakan suatu perasaan yang wajib dari individu untuk bertahan dalam organisasi. Normatif merupakan perasaan-perasaan seorang karyawan tentang kewajiban yang harus dia berikan kepada organisasi, dan tindakan tersebut merupakan hal benar yang harus dilakukan.

\section{d. Kepuasan Kerja}

Gibson et al (2012), mengatakan bahwa kepuasan kerja adalah suatu perilaku individu yang berkaitan dengan pekerjaannya, dan kepuasan kerja juga merupakan persepsi atas pekerjaan yang berhubungan dengan faktor lingkungan seperti gaya kepemimpinan supervisor, prosedur, peraturan, hubungan suatu kelompok, kondisi pekerjaan, dan tunjungan. Sementara, Spector (2000), mendefinisikan kepuasan kerja sebagai sebuah sikap yang merefleksikan bagaimana perasaan seseorang terhadap pekerjaannya secara keseluruhan maupun terhadap berbagai aspek yang ada pada pekerjaannya. Gibson et al (2012), membagi dimensi yang membentuk kepuasan kerja menjadi lima dimensi, yaitu: pertama, Gaji, ini mengukur kepuasan karyawan yang berhubungan dengan gaji yang diterimanya dan adanya kenaikan gaji, yaitu besarnya gaji yang diterima sesuai dengan tingkat yang dianggap sepadan. Kedua, pekerjaan, aspek yang mengukur kepuasan kerja terhadap hal yang berkaitan dengan pekerjaan itu sendiri, seperti kesempatan untuk berkreasi dan variasi dari tugas, kesempatan untuk menyibukkan diri, tanggungjawab, peningkatan pengetahuan, job enrichment, dan kompleksitas pekerjaan. Ketiga, Kesempatan Promosi, Aspek ini mengukur sejauh mana kepuasan karyawan berkaitan dengan kebijaksanaan promosi dan kesempatan untuk mendapatkan promosi. Promosi untuk meningkatkan karir juga akan memberikan pengaruh terhadap kepuasan kerja karyawan. Keempat, kepemimpinan, aspek ini mengukur kepuasan kerja seorang karyawan terhadap atasannya. Karyawan yang menyukai bekerja dengan atasan yang bersifat mendukung, penuh perhatian, bersahabat, memberi pujian atas kinerja yang baik dari bawahan, mendengar pendapat dari bawahan, daripada bekerja 
dengan pimpinan yang bersifat acuh tak acuh, kasar dan memusatkan dirinya pada pekerjaan daripada karyawan. Kelima, rekan kerja, aspek ini mengukur kepuasan kerja yang berkaitan antara hubungan dengan reka kerja. Rekan kerja yang memberikan dukungan terhadap rekannya yang lain serta suasana kerja yang nyaman dapat meningkatkan kepuasan kerja karyawan.

\section{PERUMUSAN HIPOTESIS}

\section{a. Hubungan Kecerdasan Emosional dengan Komitmen Organisasional}

Hasil dari penelitian ini sesuai dengan penelitian - penelitian terdahulu Shafiq dan Rana (2016), yang menemukan bahwa kecerdasan emosional memiliki pengaruh hubungan yang positif dan secara signifikan terhadap komitmen organisasional. Begitu pula dengan penelitian yang dilakukan oleh Alavi et al., (2013), yang menyatakan bahwa ada pengaruh positif dari kecerdasan emosional dengan komitmen organisasional. Temuan ini diperkuat juga oleh penelitian yang dilakukan oleh Sarawati dan Johar (2014), dimana hasil yang ditemukan sama dengan sebelumnya yaitu ada pengaruh positif antara kecerdasan emosional terhadap komitmen organisasional. Hal ini berarti menunjukkan bahwa karyawan yang memiliki kecerdasan emosional akan lebih cenderung memiliki tingkat komitmen yang tinggi terhadap suatu organisasi.

\section{H1: kecerdasan emosional mempunyai pengaruh yang positif terhadap komitmen organisasional}

\section{b. Hubungan Pemberdayaan Karyawan dengan Komitmen Organisasional}

Hasil dari penelitian ini sesuai dengan penelitian - penelitian terdahulu Hanaysha (2016), yang menyatakan bahwa terdapat pengaruh positif yang dilakukan oleh pemberdayan karyawan terhadap komitmen organisasional. Hasil ini sama dengan penelitian terdahulu yang dilakukan oleh Goundarzavand dan Kheradmand (2013), yang mengungkapkan adanya pengaruh positif dan signifikan antara pemberdayaan karyawan dengan komitmen organisasional. Lebih lanjut Parameswari dan Rahyuda (2014), menjelaskan bahwa seharusnya organisasi lebih membebaskan para karyawannya atau dengan kata lain lebih memberbadayakan para karyawan seperti melibatkan dalam proses pengambilan keputusan dan kebijakan organisasi, mengembangkan hal inisiatif yang dimiliki para karyawan supaya karyawan akan merasa kontribusi mereka dalam bekerja di organisasi lebih bermakna dalam memajukan organisasi.

H2: pemberdayaan karyawan mempunyai pengaruh yang positif terhadap komitmen organisasional

\section{c. Hubungan Kecerdasan Emosional dengan Kepuasan Kerja}

Hasil dari penelitian ini sesuai dengan penelitian - penelitian terdahulu Seyal dan Afzaal (2013), menyatakan dalam penelitiannya bahwa terdapat hubungan pengaruh yang positif dari kecerdasan emosional dengan kepuasan kerja. Hal ini juga sesuai dengan hasil penelitian yang dilakukan oleh Badawy dan Magdy (2015), menyatakan bahwa ada pengaruh positif dan signifikan dari kecerdasan emosional terhadap kepuasan kerja. Sementara Yahyazadeh (2012), menyarankan untuk adanya pelatihan yang di lakukan organisasi bagi para karyawan guna meningkatkan kecerdasan emosional berdasarkan tingkat kepuasan kerja mereka sendiri.

\section{H3: kecerdasan emosional mempunyai pengaruh yang positif terhadap kepuasan kerja}

\section{d. Hubungan Pemberdayaan Karyawan dengan Kepuasan Kerja}

Hasil dari penelitian ini sesuai dengan penelitian - penelitian terdahulu Raza et al (2015), menyatakan bahwa ada pengaruh positif yang dilakukan oleh pemberdayaan karyawan terhadap kepuasan kerja seorang karyawan. Begitu pula dengan penelitian terdahulu yang dilakukan oleh 
Sobhani (2016), yang mengatakan bahwa terdapat pengaruh yang positif serta signifikan antara pemberdayaan karyawan dengan kepuasan kerja. Surekha dan Singh (2016), mengatakan bahwa organisasi harus menyadari akan peran penting dari pemberdayaan terhadap karyawan karena secara langsung akan dapat meningkatkan kepuasan kerja para karyawan yaitu dengan memberikan karyawan kebebasan dan menjadikan karyawan sebagai kuci dari organisasi.

\section{H4: pemberdayaan karyawan mempunyai pengaruh yang positif terhadap kepuasan kerja}

\section{e. Hubungan Kepuasan Kerja dengan Komitmen Organisasional}

Hasil dari penelitian ini sesuai dengan penelitian - penelitian terdahulu Azeem dan Akhtar (2014), menyatakan bahwa kepuasan kerja memiliki pengaruh yang positif terhadap komiten organisasi. Begitu juga dengan penelitian yang telah dilakukan oleh Auda (2016) mengungkapkan bahwa terdapat hubungan positif antara kepuasan kerja dengan komitmen organisasional. . Ini mengindikasikan bahwa organisasi harus mampu memberikan beberapa hal dan sarana penunjang dalam organisasi yang bisa dilakukan untuk meningkatkan kepuasan kerja para karyawan.

\section{H5: kepuasan kerja mempunyai pengaruh yang positif terhadap komitmen organisasional}

\section{f. Hubungan Kecerdasan Emosional dengan Komitmen Organisasional yang Dimediasi oleh Kepuasan Kerja}

Kecerdasan emosional diketahui mempunyai hubungan yang positif terhadap kepuasan kerja (Elias at al 2012, Seyal dan Afzaal 2013, Badawy dan Magdy 2015), dan kepuasan kerja memiliki hubungan pengaruh yang positif terhadap komitmen organisasional (Auda 2016, Azeem dan Akhtar 2014, Aghdasi, Gangai dan Agrawal 2015). Lebih lanjut dijelaskan bahwa karyawan yang memiliki tingkat kecerdasan emosional yang tinggi akan lebih mudah dalam mengendalikan pekerjaan dan merasakan tingkat kepuasan kerja yang tinggi, dan karyawan yang memiliki kepuasan kerja yang tinggi cenderung akan lebih memilih bertahan didalam organi sasi dan memiliki komitmen yang tinggi terhadap organisasi.

H6: kepuasan kerja akan memediasi hubungan antara kecerdasan emosional dengan komitmen organisasional

\section{g. Hubungan Pemberdayaan Karyawan dengan Komitmen Organisasional yang Dimediasi oleh Kepuasan Kerja}

Kepuasan kerja telah ditemukan memiliki efek mediasi (Gulleryuz et al, 2008). Didalam penelitiannya kepuasan kerja dapat memediasi hubungan antara pemberdayaan karyawan, kecerdasan emosional, dan komitmen organisasional. Selain itu penelitian yang dilakukan oleh Goundarzavand dan Kheradmand (2013), menjelaskan tentang adanya hubungan positif antara pemberdayaan karyawan dengan komitmen organisasional. Sementara kepuasan kerja mampu menjadi mediasi hubungan antara pemberdayaan karyawan dengan komitmen organisasional, dimana seorang karyawan yang memiliki kepuasan kerja karena merasa dirinya diberdayakan didalam organisasi maka tingkat komitmen seorang karyawan akan semakin meningkat.

H7: kepuasan kerja akan memediasi hubungan antara pemberdayaan karyawan dengan komitmen organisasional

\section{KERANGKA PEMIKIRAN PENELITIAN}

Berdasarkan pada tinjauan pustaka, hubungan antar variabel, dan hipotesis yang telah dijelaskan sebelumnya, maka kerangka pemikiran dalam penelitian ini adalah 


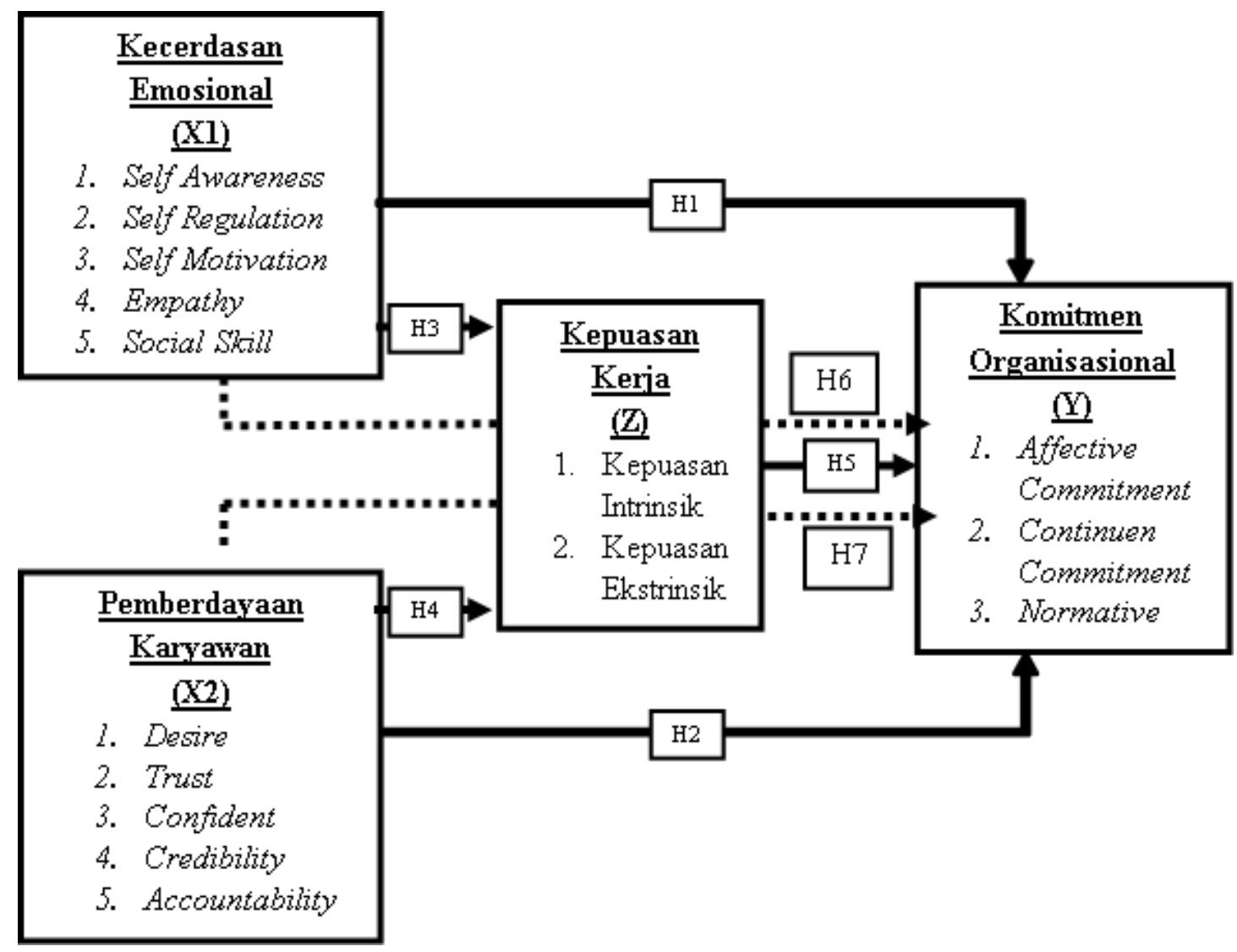

\section{METODE PENELITIAN}

Penelitian ini menggunakan pendekatan kuantitatif. Pendekatan kuantitatif didasarkan pada pengukuran variabel bagi partisipan untuk mendapatkan skor, yang biasanya berbentuk angka, dikumpulkan untuk analisis statistik untuk diringkas dan diinterprestasikan (Gravetter and Forzano, 2015).

\section{a. Variabel Penelitian}

Variabel bebas merupakan variabel - variabel yang menyebabkan, memengaruhi, atau berefek pada outcome. Variabel ini juga dikenal dengan istilah variabel treatment, manipulated, antecedent, atau predictor (Creswell, 2009). Variabel bebas dalam penelitian ini adalah kecerdasan emosional dan pemberdayaan karyawan. Variabel terikat merupakan variabel yang bergantung pada variabel - variabel bebas. Variabel terikat ini merupakan outcome atau hasil dari pengaruh variabel - variabel bebas. Nama lain dari variabel ini adalah criterion, outcome dan effect variables (Creswell, 2009). Variabel terikat dalam penelitian ini adalah komitmen organisasional. Variabel intervening atau mediating berarti berada antara variabel bebas dan variabel terikat. Variabel ini memediasi pengaruh - pengaruh variabel bebas terhadap variabel dependen (Creswell, 2009). Variabel mediasi dalam penelitian ini adalah kepuasan kerja.

\section{b. Definisi Operasional Variabel Penelitian dan Indikator}

\section{1) Kecerdasan Emosional}

Kecerdasan emosional menurut Goleman (2003), merupakan suatu kemampuan dalam mengenali perasaan diri sendiri dan perasaan orang lain, serta dapat memotivasi diri sendiri, dan mampu mengelola emosi dengan baik untuk diri sendiri dan juga dalam hubungan dengan orang lain. Menurut Goleman (2003), terdapat beberapa dimensi dan indikator dalam kecerdasan emosional, yaitu: Self Awareness, Self regulation, Self Motivation, Empathy, Social skill. 


\section{2) Pemberdayaan Karyawan}

Pemberdayaan karyawan merupakan pemberian kesempatan dan dorongan kepada karyawan untuk mendayagunakan bakat, keterampilan, sumber daya, dan pengalaman mereka untuk menyelesaikan pekerjaan secara tepat waktu, serta karyawan diberikan kepercayaan dan kewenangan yang nantinya dapat menumbuhkan rasa tanggungjawab. Pengukuran pemberdayaan karyawan pada penelitian ini mengacu pada parameter yang dibuat oleh Khan (1997) yaitu: desire, trust, confident, credibility, accountability, communication.

\section{3) Komitmen Organisasional}

Komitmen organisasional adalah suatu konstruk psikologis yang merupakan karakteristik hubungan anggota organisasi dengan organisasinya dan memiliki implikasi terhadap keputusan individu untuk melanjutkan keanggotaannya dalam berorganisasi dengan bergantung pada nilai -nilai organisasi. Pengukuran komitmen organisasionalonal pada penelitian ini mengacu pada parameter yang dibuat oleh (Allen dan Meyer, 1990), yaitu: affective commitment, continuen commitment, normative commitment.

\section{4) Kepuasan Kerja}

Kepuasan kerja biasanya diperlakukan sebagai kumpulan perasaan atau tanggapan afektif yang terkait dengan situasi pekerjaan, atau hanya bagaimana yang orang rasakan tentang berbagai aspek pekerjaan mereka (Spector, 1997). Indikator kepuasan kerja, diantaranya yaitu : promosi, pengawasan, rekan kerja, sifat pekerjaan, kondisi pekerjaan, kondisi operasional, komunikasi, gaji, imbalan kontingensi, penghargaan.

\section{c. Sampel penelitian}

Penelitian ini dilakukan pada karyawan PNS yang ada di Dinas Sosial Daerah Istimewa Yogyakarta, dimana seluruh populasi diambil sebagai sampel (metode sensus). Ada sebanyak 125 kuisioner yang disebar dengan tingkat pengembalian kuisioner sebanyak 107 kuisioner.

\section{d. Metode Analisis Data}

\section{Tahapan Analisis PLS - SEM}

Tahapan analisis menggunakan PLS - SEM setidaknya harus melalui lima proses dimana setiap tahapan akan berpengaruh terhadap tahapan selanjutnya, yaitu (a) konseptualisasi model, (b) menentukan metoda analisis algorithm, (c) menentukan metoda resampling, (d) menggambar diagram jalur dan (e) evaluasi model (Ghozali and Latan, 2015).

\section{1) Konseptualiasasi Model}

Konseptualisasi model merupakan langkah awal dalam analisis PLS - SEM. Pada tahap ini peneliti harus melakukan pengembangan dan pengukuran konstruk. Terdapat beberapa proses dalam tahap ini. (1) spesifikasi domain konstruk, (2) menentukan item yang merepresentasi konstruk, (3) pengumpulan data untuk dilakukan uji pretest, (4) purifikasi konstruk, (5) pengumpulan data baru,(6) uji reliabilitas, (7) uji validitas, dan (8) menentukan skor pengukuran konstruk. Selanjutnya arah kausalitas antar konstruk yang menunjukan hubungan yang dihipotesiskan harus ditentukan dengan jelas dan dimensionalitas serta indikator pembentuk konstruk laten harus ditentukan apakah berbentuk refleksif ataukah fotmatif.

\section{2) Menentukan Metoda Analisis Algorithm}

Model penelitian yang sudah melewati tahapan konseptualisasi model selanjutnya harus ditentukan metoda analisis algorithm apa yang akan digunakan untuk estimasi model. Dalam PLS - SEM menngunakan program SmartPLS 3.0, metoda analisis algorithm yang disediakan hanyalah algorithm PLS dengan tiga pilihan skema yaitu, 
factorial, centroid, dan path atau structural weighting. Skema algorithm PLS yang disarankan adalah path atau structural weighting.

\section{3) Menentukan Metoda Resampling}

Umumnya, terdapat dua metoda resampling yang digunakan oleh peneliti di bidang SEM untuk melakukan proses penyampelan kembali, yaitu metoda botstarpping dan jacknifing. Dalam penelitian ini, digunakan metode botsrapping, yaitu metode yang menggunakan seluruh sampel asli untuk melakukan penyampelan kembali. Metoda ini lebih sering digunakan dalam model persamaan struktural. Dalam SmartPLS hanya terdapat metode resampling yaitu metode botstrapping dengan tiga pilihan yaitu no sign changes, Individual sign changes, dan construct level changes.

4) Menggambar Diagram Jalur

Setelah melakukan konseptualisasi model, menentukan metoda analisis algorithm dan metoda resampling, langkah selanjutnya adalah menggambar diagram jalur dari model yang akan diestimasi tersebut. Dalam menggambar diagram jalur (path diagram).

\section{5) Evaluasi Model}

Setelah menggambar diagram jalur, maka model siap untuk diestimasi dan dievaluasi hasilnya secara keseluruhan. Evaluasi model dalam PLS - SEM menggunakan program SmartPLS 3.0 dapat dilakukan dengan menilai hasil pengukuran (measurement model) yaitu melalui analisis faktor konfirmatori atau confirmatory factor analysis dengan menguji validitas dan reliabilitas konstruk laten. Kemudian dilanjutkan dengan evaluasi model struktural dan pengujian signifikansi untuk menguji pengaruh antar konstruk atau variabel. Model evaluasi PLS dilakukan dengan menilai outer dan inner model. Evaluasi model pengukuran (outer model) dilakukan untuk menilai validitas dan reliabilitas model. Outer model dengan indikator refleksif dievaluasi melalui validitas covergent dan discriminant dari indikator pembentuk konstruk laten dan composite reliability serta cronbach alpha untuk blok indikatornya.

\section{HASIL DAN PEMBAHASAN}

\section{a. Pengujian Model Pengukuran}

\section{1) Convergent Validity}

Model pengukuran menunjukkan bagaimana variabel manifest atau observed variabel merepresentasi variabel laten untuk diukur. Convergent validity diukur dengan menggunakan parameter outer loading dan AVE (Average Variance Extraced). Ukuran refleksif individual dikatakan berkolerasi jika nilai lebih dari 0,7 dengan konstruk yang ingin diukur (Ghozali and Latan, 2015). Dari hasi analisis model pengukuran, diketahi bahwa terdapat beberapa variabel manifest yang nilai factor loading nya $<0.70$, sehingga untuk memenuhi rule of thumb nya, maka variabel manifest yang nilainya $<0.70$ harus di drop dari model. Variabel manifest yang harus dikeluarkan dari model adalah variabel SS3, TR1, AC1, AC4, PR1, PR3, SP3, KOP1, GA2, dan KN1.

Tabel 1. Rangkuman Nilai Loading Factor

\begin{tabular}{|c|c|c|c|}
\hline Variabel Laten & Indikator & Kode Item & Loading Factor \\
\hline \multirow{2}{*}{$\begin{array}{c}\text { Kecerdasan } \\
\text { Emosional }\end{array}$} & Self Awareness & SA1 & 0.715 \\
\cline { 3 - 4 } & & SA2 & 0.813 \\
\cline { 2 - 3 } & SA3 & 0.788 \\
\hline
\end{tabular}




\begin{tabular}{|c|c|c|c|}
\hline Variabel Laten & Indikator & Kode Item & Loading Factor \\
\hline & \multirow{3}{*}{ Self Regulation } & SR1 & 0.771 \\
\hline & & SR2 & 0.816 \\
\hline & & SR3 & 0.823 \\
\hline & \multirow{3}{*}{ Self Motivation } & SM1 & 0.752 \\
\hline & & SM2 & 0.888 \\
\hline & & SM3 & 0.826 \\
\hline & \multirow{3}{*}{ Empathy } & EM1 & 0.846 \\
\hline & & EM2 & 0.853 \\
\hline & & EM3 & 0.851 \\
\hline & \multirow{2}{*}{ Social Skill } & SS1 & 0.834 \\
\hline & & SS2 & 0.825 \\
\hline \multirow{17}{*}{$\begin{array}{c}\text { Pemberdayaan } \\
\text { Karyawan }\end{array}$} & \multirow{4}{*}{ Desire } & DE1 & 0.749 \\
\hline & & DE2 & 0.852 \\
\hline & & DE3 & 0.888 \\
\hline & & DE4 & 0.750 \\
\hline & \multirow{3}{*}{ Trust } & TR2 & 0.797 \\
\hline & & TR3 & 0.773 \\
\hline & & TR4 & 0.786 \\
\hline & \multirow{4}{*}{ Confident } & CON1 & 0.797 \\
\hline & & CON2 & 0.898 \\
\hline & & CON3 & 0.812 \\
\hline & & CON4 & 0.742 \\
\hline & \multirow{3}{*}{ Credibility } & CR1 & 0.762 \\
\hline & & CR2 & 0.873 \\
\hline & & CR3 & 0.840 \\
\hline & \multirow{2}{*}{ Accountability } & $\mathrm{AC2}$ & 0.835 \\
\hline & & $\mathrm{AC3}$ & 0.816 \\
\hline & Communication & COM1 & 0.860 \\
\hline
\end{tabular}




\begin{tabular}{|c|c|c|c|}
\hline Variabel Laten & Indikator & Kode Item & Loading Factor \\
\hline & & COM2 & 0.844 \\
\hline & & COM3 & 0.763 \\
\hline \multirow{22}{*}{ Kepuasan Kerja } & Promosi & PR2 & 0.857 \\
\hline & \multirow{3}{*}{ Supervise/Pengawasan } & SU1 & 0.830 \\
\hline & & SU2 & 0.898 \\
\hline & & SU3 & 0.813 \\
\hline & \multirow{3}{*}{ Rekan Kerja } & RK1 & 0.886 \\
\hline & & RK2 & 0.868 \\
\hline & & RK3 & 0.867 \\
\hline & \multirow{2}{*}{ Sifat Pekerjaan } & SP1 & 0.917 \\
\hline & & SP2 & 0.871 \\
\hline & Kondisi Operasional & KOP2 & 0.906 \\
\hline & \multirow{3}{*}{ Komunikasi } & KOM1 & 0.859 \\
\hline & & КОМ2 & 0.893 \\
\hline & & KOM3 & 0.879 \\
\hline & \multirow{2}{*}{ Gaji } & GA1 & 0.765 \\
\hline & & GA3 & 0.796 \\
\hline & \multirow{3}{*}{ Imbalan Kontigensi } & IK1 & 0.819 \\
\hline & & IK2 & 0.788 \\
\hline & & IK3 & 0.742 \\
\hline & \multirow{4}{*}{ Penghargaan } & PE1 & 0.800 \\
\hline & & PE2 & 0.794 \\
\hline & & PE3 & 0.876 \\
\hline & & PE4 & 0.870 \\
\hline \multirow{4}{*}{$\begin{array}{c}\text { Komitmen } \\
\text { Organisasional }\end{array}$} & \multirow{4}{*}{ Komitmen Afektif } & KA1 & 0.848 \\
\hline & & KA2 & 0.834 \\
\hline & & KA3 & 0.899 \\
\hline & & KA4 & 0.865 \\
\hline
\end{tabular}




\begin{tabular}{|l|c|c|c|}
\hline Variabel Laten & Indikator & Kode Item & Loading Factor \\
\hline \multirow{3}{*}{ Komitmen Kontinyu } & KKN1 & 0.782 \\
\cline { 3 - 4 } & & KKN2 & 0.866 \\
\cline { 3 - 4 } & & KKN3 & 0.771 \\
\cline { 2 - 4 } & \multirow{3}{*}{ Komitmen Normatif } & KKN4 & 0.731 \\
\cline { 2 - 4 } & & KN2 & 0.862 \\
\cline { 2 - 4 } & & KN3 & 0.831 \\
\cline { 2 - 4 } & & KN4 & 0.802 \\
\hline
\end{tabular}

Tabel diatas menunjukkan nilai - nilai factor loading dari semua variabel manifest yang diuji. Dari tabel tersebut dapat dilihat bahwa semua nilai factor loading $>0.70$, sehingga semua variabel manifest telah memenuhi kaidah - kaidah model pengukuran dan bisa dilanjutkan untuk pengujian selanjutnya.

\section{2) Discriminant validity}

Discriminant validity digunakan untuk menguji validitas suatu model. Discriminant validity dilihat melalui nilai cross loading yang menunjukkan besarnya korelasi antar konstruk dengan indikatornya dan indikator dari konstruk lainnya. Standar nilai yang digunakan untuk cross loading yaitu harus lebih besar dari 7 atau dengan membandingkan nilai square root of average variance extracted (AVE) setiap konstruk dengan korelasi antara konstruk dengan konstruk lainnya dalam model. Jika nilai akar AVE setiap konstruk lebih besar dari pada nilai korelasi antara konstruk dengan konstruk lainnya dalam model, maka dikatakan memiliki nilai discriminant validity yang baik.

Tabel 2. Nilai Cross Loading

\begin{tabular}{|c|c|c|c|c|}
\hline Item & KCEM & PMBDKY & KPSKJ & KMORG \\
\hline SA1 & $\mathbf{0 . 4 9 7}$ & 0.322 & 0.222 & 0.288 \\
\hline SA2 & $\mathbf{0 . 5 2 0}$ & 0.277 & 0.136 & 0.203 \\
\hline SA3 & $\mathbf{0 . 5 4 2}$ & 0.380 & 0.203 & 0.322 \\
\hline SR1 & $\mathbf{0 . 5 6 6}$ & 0.377 & 0.278 & 0.347 \\
\hline SR2 & $\mathbf{0 . 6 7 5}$ & 0.407 & 0.285 & 0.215 \\
\hline SR3 & $\mathbf{0 . 6 3 0}$ & 0.296 & 0.222 & 0.234 \\
\hline SM1 & $\mathbf{0 . 6 1 8}$ & 0.207 & 0.172 & 0.204 \\
\hline SM2 & $\mathbf{0 . 5 7 4}$ & 0.082 & 0.280 & 0.218 \\
\hline SM3 & $\mathbf{0 . 5 8 7}$ & 0.228 & 0.312 & 0.277 \\
\hline EM1 & $\mathbf{0 . 6 4 4}$ & 0.231 & 0.416 & 0.292 \\
\hline
\end{tabular}




\begin{tabular}{|c|c|c|c|c|}
\hline Item & КСЕM & PMBDKY & KPSKJ & KMORG \\
\hline EM2 & 0.623 & 0.173 & 0.365 & 0.264 \\
\hline EM3 & 0.713 & 0.333 & 0.345 & 0.244 \\
\hline SS1 & 0.643 & 0.313 & 0.174 & 0.256 \\
\hline $\mathrm{SS} 2$ & 0.554 & 0.235 & 0.140 & 0.063 \\
\hline DE1 & 0.332 & 0.469 & 0.397 & 0.257 \\
\hline DE2 & 0.388 & 0.556 & 0.359 & 0.317 \\
\hline DE3 & 0.402 & 0.660 & 0.327 & 0.331 \\
\hline DE4 & 0.343 & 0.569 & 0.247 & 0.325 \\
\hline TR2 & 0.452 & 0.648 & 0.342 & 0.376 \\
\hline TR3 & 0.230 & 0.547 & 0.172 & 0.421 \\
\hline TR4 & 0.243 & 0.710 & 0.286 & 0.330 \\
\hline CON1 & 0.231 & 0.607 & 0.239 & 0.157 \\
\hline CON2 & 0.338 & 0.709 & 0.288 & 0.091 \\
\hline CON3 & 0.248 & 0.601 & 0.132 & 0.039 \\
\hline CON4 & 0.311 & 0.670 & 0.297 & 0.346 \\
\hline CR1 & 0.232 & 0.599 & 0.214 & 0.293 \\
\hline CR2 & 0.296 & 0.654 & 0.181 & 0.273 \\
\hline CR3 & 0.217 & 0.645 & 0.120 & 0.200 \\
\hline $\mathrm{AC} 2$ & 0.159 & 0.625 & 0.316 & 0.392 \\
\hline $\mathrm{AC} 3$ & 0.392 & 0.657 & 0.386 & 0.329 \\
\hline COM1 & 0.372 & 0.687 & 0.322 & 0.366 \\
\hline COM2 & 0.323 & 0.706 & 0.267 & 0.384 \\
\hline COM3 & 0.191 & 0.586 & 0.252 & 0.291 \\
\hline PR2 & 0.266 & 0.155 & 0.279 & 0.269 \\
\hline SU1 & 0.254 & 0.266 & 0.571 & 0.368 \\
\hline SU2 & 0.297 & 0.262 & 0.571 & 0.344 \\
\hline SU3 & 0.359 & 0.230 & 0.683 & 0.322 \\
\hline RK1 & 0.381 & 0.314 & 0.638 & 0.311 \\
\hline
\end{tabular}




\begin{tabular}{|c|c|c|c|c|}
\hline Item & KCEM & PMBDKY & KPSKJ & KMORG \\
\hline RK2 & 0.376 & 0.275 & 0.612 & 0.270 \\
\hline RK3 & 0.437 & 0.257 & 0.676 & 0.173 \\
\hline SP1 & 0.446 & 0.262 & 0.616 & 0.319 \\
\hline $\mathrm{SP} 2$ & 0.316 & 0.266 & 0.596 & 0.304 \\
\hline KOP2 & 0.319 & 0.241 & 0.652 & 0.269 \\
\hline KOM1 & 0.252 & 0.260 & 0.678 & 0.219 \\
\hline KOM2 & 0.185 & 0.299 & 0.701 & 0.273 \\
\hline KOM3 & 0.274 & 0.296 & 0.696 & 0.277 \\
\hline GA1 & 0.250 & 0.129 & 0.563 & 0.229 \\
\hline GA3 & 0.233 & 0.172 & 0.605 & 0.196 \\
\hline IK1 & 0.304 & 0.341 & 0.740 & 0.275 \\
\hline $\mathrm{IK} 2$ & 0.167 & 0.303 & 0.545 & 0.239 \\
\hline IK3 & 0.018 & 0.175 & 0.548 & 0.249 \\
\hline PE1 & 0.287 & 0.383 & 0.687 & 0.361 \\
\hline PE2 & 0.266 & 0.244 & 0.685 & 0.307 \\
\hline PE3 & 0.341 & 0.317 & 0.765 & 0.292 \\
\hline PE4 & 0.253 & 0.276 & 0.739 & 0.276 \\
\hline KA1 & 0.386 & 0.390 & 0.279 & 0.788 \\
\hline KA2 & 0.394 & 0.420 & 0.492 & 0.654 \\
\hline KA3 & 0.434 & 0.465 & 0.392 & 0.801 \\
\hline KA4 & 0.445 & 0.485 & 0.365 & 0.739 \\
\hline KKN1 & 0.409 & 0.371 & 0.297 & 0.697 \\
\hline KKN2 & 0.194 & 0.124 & 0.209 & 0.622 \\
\hline KKN3 & 0.135 & -0.029 & 0.183 & 0.439 \\
\hline KKN4 & 0.223 & 0.114 & 0.161 & 0.631 \\
\hline $\mathrm{KN} 2$ & 0.137 & 0.383 & 0.371 & 0.661 \\
\hline KN3 & 0.240 & 0.364 & 0.412 & 0.674 \\
\hline KN4 & 0.141 & 0.282 & 0.348 & 0.677 \\
\hline
\end{tabular}


Berdasarkan pada tabel diatas, nilai cross loading pada masing - masing item memiliki nilai yang lebih besar dari nilai square root of average variance extracted (AVE), dan nilai paling besar saat dihubungkan dengan variabel latennya dibandingkan dengan ketika dihubungkan dengan variabel laten lain. Hal ini menunjukkan bahwa setiap variabel manifest dalam penelitian ini telah tepat menjelaskan variabel latennya dan membuktikan bahwa discriminant validity seluruh item valid.

\section{3) Second Order Confirmatory Analysis}

Second order confirmatory analysis merupakan hubungan teoritis antara variabel laten atau konstruk high order dengan dimensi konstruk dibawahnya (Jogiyanto, 2011).

Tabel 3. Path Coefficient Pengukuran Signifikansi SCFA

\begin{tabular}{|c|c|c|c|c|c|}
\hline Konstruk & $\begin{array}{c}\text { Original } \\
\text { Sample (O) }\end{array}$ & $\begin{array}{c}\text { Sample } \\
\text { Mean (M) }\end{array}$ & $\begin{array}{l}\text { Standard } \\
\text { Deviation } \\
\text { (STDEV) }\end{array}$ & $\begin{array}{r}\text { T Statistics } \\
(\mid \text { O/STDEV|) }\end{array}$ & P Values \\
\hline AC -> PMBDKY & 0.189 & 0.190 & 0.023 & 8.287 & 0.000 \\
\hline COM -> PMBDKY & 0.200 & 0.198 & 0.024 & 8.350 & 0.000 \\
\hline CON -> PMBDKY & 0.263 & 0.259 & 0.027 & 9.571 & 0.000 \\
\hline CR -> PMBDKY & 0.211 & 0.210 & 0.023 & 9.253 & 0.000 \\
\hline DE -> PMBDKY & 0.250 & 0.252 & 0.036 & 7.003 & 0.000 \\
\hline EM -> KCEM & 0.358 & 0.357 & 0.036 & 9.830 & 0.000 \\
\hline GA -> KPSKJ & 0.104 & 0.103 & 0.021 & 5.069 & 0.000 \\
\hline IK -> KPSKJ & 0.171 & 0.170 & 0.024 & 7.249 & 0.000 \\
\hline KA -> KMORG & 0.503 & 0.503 & 0.043 & 11.729 & 0.000 \\
\hline KKN -> KMORG & 0.384 & 0.378 & 0.044 & 8.643 & 0.000 \\
\hline KN -> KMORG & 0.345 & 0.343 & 0.027 & 12.892 & 0.000 \\
\hline KOM -> KPSKJ & 0.224 & 0.222 & 0.027 & 8.282 & 0.000 \\
\hline KOP -> KPSKJ & 0.067 & 0.069 & 0.017 & 3.967 & 0.000 \\
\hline PE -> KPSKJ & 0.235 & 0.233 & 0.024 & 9.843 & 0.000 \\
\hline PR -> KPSKJ & 0.163 & 0.160 & 0.033 & 6.908 & 0.000 \\
\hline RK -> KPSKJ & 0.156 & 0.155 & 0.023 & 6.780 & 0.000 \\
\hline SA -> KCEM & 0.222 & 0.221 & 0.035 & 6.276 & 0.000 \\
\hline SM -> KCEM & 0.272 & 0.271 & 0.035 & 7.878 & 0.000 \\
\hline SP -> KPSKJ & 0.146 & 0.148 & 0.023 & 6.472 & 0.000 \\
\hline SR -> KCEM & 0.310 & 0.306 & 0.034 & 9.037 & 0.000 \\
\hline
\end{tabular}




\begin{tabular}{|c|c|c|c|c|c|}
\hline Konstruk & $\begin{array}{c}\text { Original } \\
\text { Sample (O) }\end{array}$ & $\begin{array}{c}\text { Sample } \\
\text { Mean (M) }\end{array}$ & $\begin{array}{c}\text { Standard } \\
\text { Deviation } \\
\text { (STDEV) }\end{array}$ & $\begin{array}{c}\text { T Statistics } \\
(\mid \mathbf{O} / \text { STDEV })\end{array}$ & P Values \\
\hline SS -> KCEM & 0.187 & 0.185 & 0.030 & 6.291 & 0.000 \\
\hline SU -> KPSKJ & 0.206 & 0.200 & 0.030 & 6.786 & 0.000 \\
\hline TR -> PMBDKY & 0.192 & 0.193 & 0.021 & 8.968 & 0.000 \\
\hline
\end{tabular}

Berdasarkan hasil path coefficient yang terdapat pada tabel diatas menunjukkan bahwa seluruh item signifikan terhadap konstruknya dengan nilai t-statistik>1.96 dan pvalues $<0.05$. Dengan demikian dapat dinyatakan bahwa indikator EM, SA, SM, SR, SS merupakan variabel manifest pembentuk konstruk Kecerdasan Emosional (KCEM), indikator AC, COM, CON, CR, DE, TR merupakan variabel manifest pembentuk konstruk Pemberdayaan Karyawan (PMBDKY), indikator GA, IK, KOM, KOP, PE, PR, RK, SP, SU merupakan variabel manifest pembentuk konstruk Kepuasan Kerja (KPSKJ), kemudian indikator KA, KKN, KN merupakan variabel manifest pembentuk konstruk Komitmen Organisasional (KMORG).

\section{b. Analisis Model Struktural (Inner Model)}

1) $R$-Square $\left(R^{2}\right)$

Tabel 4. Path Coefficient Pengukuran Signifikansi SCFA

\begin{tabular}{|c|c|c|}
\hline Variabel & R Square & R Square Adjusted \\
\hline KMORG & 0.389 & 0.371 \\
\hline KPSKJ & 0.286 & 0.272 \\
\hline
\end{tabular}

Berdasarkan tabel dapat dilihat bahwa model pengaruh kecerdasan emosional dan pemberdayaan karyawan terhadap komitmen organisasional memberikan nilai sebesar 0.389 , yang dapat diinterprestasikan bahwa variabilitas konstruk komitmen organisasional yang dapat dijelaskan oleh variabilitas konstruk kecerdasan emosional dan pemberdayaan karyawan adalah sebesar 38.9\% sedangkan sisanya dijelaskan oleh variabel lain diluar penelitian ini. Begitu juga dengan model pengaruh kecerdasan emosional dan pemberdayaan karyawan terhadap kepuasan kerja memberikan nilai sebesar 0.286 , yang dapat diinterprestasikan bahwa variabilitas konstruk kepuasan kerja yang dapat dijelaskan oleh variabilitas konstruk kecerdasan emosional dan pemberdayaan karyawan adalah sebesar $28.6 \%$, sedangkan sisanya dijelaskan oleh variabel - variabel diluar penelitian ini

\section{2) Uji Hipotesis}

Tabel 5. Path Coefficient

\begin{tabular}{|c|c|c|c|c|c|}
\hline Konstruk & $\begin{array}{c}\text { Original } \\
\text { Sample (O) }\end{array}$ & $\begin{array}{c}\text { Sample Mean } \\
(\mathbf{M})\end{array}$ & $\begin{array}{c}\text { Standard } \\
\text { Deviation } \\
\text { (STDEV) }\end{array}$ & $\begin{array}{c}\text { T Statistics } \\
(\mid \mathbf{O} / \text { STDEV|) }\end{array}$ & P Values \\
\hline $\begin{array}{c}\text { KCEM -> } \\
\text { KMORG }\end{array}$ & 0.188 & 0.203 & 0.093 & 2.014 & 0.044 \\
\hline KCEM -> & 0.320 & 0.329 & 0.123 & 2.610 & 0.009 \\
\hline
\end{tabular}




\begin{tabular}{|c|c|c|c|c|c|}
\hline Konstruk & $\begin{array}{c}\text { Original } \\
\text { Sample (O) }\end{array}$ & $\begin{array}{c}\text { Sample Mean } \\
(\mathbf{M})\end{array}$ & $\begin{array}{c}\text { Standard } \\
\text { Deviation } \\
\text { (STDEV) }\end{array}$ & $\begin{array}{c}\text { T Statistics } \\
(\mid \mathbf{O} / \text { STDEV })\end{array}$ & P Values \\
\hline KPSKJ & 0.227 & 0.227 & 0.100 & 2.261 & 0.024 \\
\hline $\begin{array}{c}\text { KPSKJ -> } \\
\text { KMORG }\end{array}$ & 0.355 & 0.360 & 0.115 & 3.086 & 0.002 \\
\hline $\begin{array}{c}\text { PMBDKY -> } \\
\text { KMORG }\end{array}$ & 0.301 & 0.323 & 0.115 & 2.623 & 0.009 \\
\hline $\begin{array}{c}\text { PMBDKY -> } \\
\text { KPSKJ }\end{array}$ & & &
\end{tabular}

Berdasarkan tabel diatas dapat dilihat bahwa konstruk kecerdasan emosional mempunyai pengaruh positif yang signifikan $(\mathrm{O}=0.188)$ dengan konstruk komitmen organisasional. Nilai $\mathrm{t}$ - statistic pada hubungan konstruk ini adalah $2.014>1.96$, dan nilai $\mathrm{p}$ - value $0.044<0.05$. oleh karena itu, hipotesis pertama yang menyatakan bahwa kecerdasan emosional mempunyai pengaruh yang positif terhadap komitmen organisasional terbukti.

Konstruk eksogen pemberdayaan karyawan mempunyai pengaruh positif yang signifikan $(\mathrm{O}=0.355)$ terhadap konstruk endogen komitmen organisasional. Hal ini berdasarkan pada nilai $\mathrm{t}$ - statistic pada hubungan konstruk ini adalah 3.086>1.96, dan nilai $\mathrm{p}$ - value $0.002<0.05$. oleh karena itu, hipotesis kedua yang menyatakan bahwa pemberdayaan karyawan mempunyai pengaruh yang positif terhadap komitmen organisasional terbukti.

Konstruk eksogen kecerdasan emosional mempunyai pengaruh positif yang signifikan $(\mathrm{O}=0.320)$ terhadap konstruk endogen kepuasan kerja. Hal ini berdasarkan pada nilai $\mathrm{t}$ - statistic pada hubungan konstruk ini adalh $2.610>1.96$, dan nilai $\mathrm{p}$ - value $0.009<0.05$. oleh karena itu, hipotesis ketiga yang menyatakan bahwa kecerdasan emosional mempunyai pengaruh yang positif terhadap kepuasan kerja terbukti.

Selain itu, konstruk eksogen pemberdayaan karyawan mempunyai pengaruh positif yang signifikan $(\mathrm{O}=0.301)$ terhadap konstruk endogen kepuasan kerja. Hal ini berdasarkan pada nilai $\mathrm{t}$ - statistic pada hubungan konstruk ini adalh $2.623>1.96$, dan nilai $\mathrm{p}$ - value $0.009<0.05$. oleh karena itu, hipotesis keempat yang menyatakan bahwa pemberdayaan karyawan mempunyai pengaruh yang positif terhadap kepuasan kerja terbukti.

Konstruk eksogen kepuasan kerja mempunyai pengaruh positif yang signifikan ( $O$ $=0.227$ ) terhadap konstruk endogen komitmen organisasional. Hal ini berdasarkan pada nilai $\mathrm{t}$ - statistic pada hubungan konstruk ini adalh $2.261>1.96$, dan nilai $\mathrm{p}$ - value $0.024<0.05$. oleh karena itu, hipotesis kelima yang menyatakan bahwa kepuasan kerja mempunyai pengaruh yang positif terhadap komitmen organisasional terbukti

\section{3) Pengujian Efek Mediasi}

Terdapat 3 syarat dalam pengujian efek mediasi (Baron and Kenny, 1986). Pertama, menguji pengaruh variabel eksogen terhadap variabel endogen dan harus signifikan pada nilai $\mathrm{t}$ - statistik $>1.96$. Kedua, menguji pengaruh variabel eksogen terhadap variabel mediasi dan harus signifikan pada nilai t- statistik $>1.96$. Ketiga, Pengujian secara simultan pengaruh variabel eksogen dan mediasi terhadap variabel endogen. Pada tahap ini efek utama diharapkan menjadi tidak signifikan, sedangkan pengaruh variabel mediasi terhadap 
variabel endogen adalah signifikan. Jika kondisi tersebut tercapai maka pengujian efek mediasi disebut sebagai efek mediasi penuh (fully mediating) (Jogiyanto, 2011).

\section{Tahap Pertama}

Tahap pertama dalam pengujian efek mediasi adalah menguji pengaruh variabel eksogen terhadap variabel endogen dan harus signifikan pada nilai $\mathrm{t}$ - statistik $>1.96$

Tabel 6. Path Coefficient Pengujian Tahap Pertama

\begin{tabular}{|c|c|c|c|c|}
\hline Konstruk & $\begin{array}{c}\text { Original } \\
\text { Sample (O) }\end{array}$ & $\begin{array}{c}\text { Sample } \\
\text { Mean (M) }\end{array}$ & $\begin{array}{c}\text { Standard } \\
\text { Deviation } \\
\text { (STDEV) }\end{array}$ & $\begin{array}{c}\text { T Statistics } \\
(\mid \mathbf{O} / \text { STDEV|) }\end{array}$ \\
\hline KCEM -> KMORG & 0.273 & 0.291 & 0.084 & 3.233 \\
\hline PMBDKY -> KMORG & 0.425 & 0.444 & 0.096 & 4.431 \\
\hline
\end{tabular}

\section{Tahap Kedua}

Pada tahap ini, dilakukan pengujian signifikansi antara variabel eksogen terhadap variabel mediasi dan harus signifikan pada nilai $\mathrm{t}-$ statistik $>1.96$.

Tabel 7. Path Coefficient Pengujian Tahap Kedua

\begin{tabular}{|c|c|c|c|c|}
\hline Konstruk & $\begin{array}{c}\text { Original } \\
\text { Sample (O) }\end{array}$ & $\begin{array}{c}\text { Sample } \\
\text { Mean (M) }\end{array}$ & $\begin{array}{c}\text { Standard } \\
\text { Deviation } \\
\text { (STDEV) }\end{array}$ & $\begin{array}{c}\text { T Statistics } \\
\text { (|O/STDEV|) }\end{array}$ \\
\hline KCEM -> KPSKJ & 0.331 & 0.346 & 0.113 & 2.915 \\
\hline PMBDKY -> KPSKJ & 0.310 & 0.349 & 0.101 & 3.074 \\
\hline
\end{tabular}

\section{Tahap Ketiga}

Pada tahap ini dilakukan pengujian secara simultan dari variabel eksogen kecerdasan emosional dan pemberdayaan karyawan, dan variabel mediasi kepuasan kerja terhadap variabel endogen komitmen organisasional.

Tabel 8. Total Effect

\begin{tabular}{|c|c|c|c|c|}
\hline Konstruk & $\begin{array}{c}\text { Original } \\
\text { Sample (O) }\end{array}$ & $\begin{array}{c}\text { Sample } \\
\text { Mean (M) }\end{array}$ & $\begin{array}{c}\text { Standard } \\
\text { Deviation } \\
\text { (STDEV) }\end{array}$ & $\begin{array}{c}\text { T Statistics } \\
(\mid \mathbf{O} / \text { STDEV|) }\end{array}$ \\
\hline KCEM -> KMORG & 0.260 & 0.275 & 0.089 & 2.909 \\
\hline KCEM -> KPSKJ & 0.320 & 0.329 & 0.123 & 2.610 \\
\hline KPSKJ -> KMORG & 0.227 & 0.227 & 0.100 & 2.261 \\
\hline PMBDKY -> KMORG & 0.423 & 0.438 & 0.101 & 4.201 \\
\hline PMBDKY -> KPSKJ & 0.301 & 0.323 & 0.115 & 2.623 \\
\hline
\end{tabular}


Tabel 9. Specific Indirect Effects

\begin{tabular}{|c|c|c|c|c|}
\hline Konstruk & $\begin{array}{c}\text { Original } \\
\text { Sample (O) }\end{array}$ & $\begin{array}{c}\text { Sample Mean } \\
\text { (M) }\end{array}$ & $\begin{array}{c}\text { Standard } \\
\text { Deviation } \\
\text { (STDEV) }\end{array}$ & $\begin{array}{c}\text { T Statistics } \\
(\mid \mathbf{O} / \text { STDEV|) }\end{array}$ \\
\hline KCEM -> KPSKJ -> KMORG & 0.073 & 0.072 & 0.040 & 2.810 \\
\hline PMBDKY -> KPSKJ -> KMORG & 0.068 & 0.078 & 0.050 & 2.376 \\
\hline
\end{tabular}

Untuk mengetahui seberapa jauh variabel kepuasan kerja bisa memdiasi hubungan antara kecerdasan emosional dan pemberdayaan karyawan terhadap komitmen organisasional dapat dilihat pada tabel specific indirect effects. Dapat dilihat dari tabel tersebut bahwa hubungan kecerdasan emosional terhadap komitmen organisasional yang dimediasi oleh kepuasan kerja masih signifikan dengan nilai $\mathrm{t}$ - statistic $2.810<1.96$, hal ini berarti bahwa kepuasan kerja berperan sebagai partial control.Partial control berarti bahwa dalam hubungan antar variabel terdapat hubungan langsung dan tidak langsung (Garson, 2016). Begitu juga dengan hubungan pemberdayaan karyawan terhadap komitmen organisasional yang dimediasi oleh kepuasan kerja masih signifikan dengan nilai $\mathrm{t}$ - statistic $2.376>1.96$, hal ini juga berarti bahwa kepuasan kerja berperan sebagai partial control dalam hubungan antara pemberdayaan karyawan terhadap komitmen organisasional.

\section{c. PEMBAHASAN}

\section{1) Pengaruh Kecerdasan Emosional terhadap Komitmen Organisasional}

Konstruk eksogen kecerdasan emosional mempunyai pengaruh positif yang signifikan $(\mathrm{O}=0.188)$ dengan konstruk komitmen organisasional. Nilai $\mathrm{t}$ - statistic pada hubungan konstruk ini adalah $2.014>1.96$, dan nilai $\mathrm{p}$ - value $0.044<0.05$. Oleh karena itu, hipotesis pertama yang menyatakan bahwa kecerdasan emosional mempunyai pengaruh yang positif terhadap komitmen organisasional terbukti kebenarannya.

Hasil dari penelitian ini sesuai dengan penelitian - penelitian terdahulu Shafiq dan Rana (2016), yang menemukan bahwa kecerdasan emosional memiliki pengaruh hubungan yang positif dan secara signifikan terhadap komitmen organisasional. Begitu pula dengan penelitian yang dilakukan oleh Alavi et al., (2013), yang menyatakan bahwa ada pengaruh positif dari kecerdasan emosional dengan komitmen organisasional. . Dengan demikian, seharusnya dalam proses seleksi dan rekrutmen yang dilakukan organisasi, kecerdasan emosional harus dimasukkan didalamnya karena dapat digunakan sebagai alat intervensi untuk meningkatkan komitmen seorang karyawan didalam organisasi.

\section{2) Pengaruh Pemberdayaan Karyawan terhadap Komitmen Organisasional}

Konstruk eksogen pemberdayaan karyawan mempunyai pengaruh positif yang signifikan $(\mathrm{O}=0.355)$ dengan konstruk komitmen organisasional. Nilai $\mathrm{t}$ - statistic pada hubungan konstruk ini adalah $3.086>1.96$, dan nilai $\mathrm{p}$ - value $0.002<0.05$. Oleh karena itu, hipotesis kedua yang menyatakan bahwa pemberdayaan karyawan mempunyai pengaruh yang positif terhadap komitmen organisasional terbukti kebenarannya.

Hasil dari penelitian ini sesuai dengan penelitian - penelitian terdahulu Hanaysha (2016), yang menyatakan bahwa terdapat pengaruh positif yang dilakukan oleh pemberdayan karyawan terhadap komitmen organisasional. seharusnya organisasi lebih membebaskan para karyawannya atau dengan kata lain lebih memberbadayakan para karyawan seperti melibatkan dalam proses pengambilan keputusan dan kebijakan 
organisasi, mengembangkan hal inisiatif yang dimiliki para karyawan supaya karyawan akan merasa kontribusi mereka dalam bekerja di organisasi lebih bermakna dalam memajukan organisasi.

\section{3) Pengaruh Kecerdasan Emosional terhadap Kepuasan Kerja}

Konstruk eksogen kecerdasan emosional mempunyai pengaruh positif yang signifikan $(\mathrm{O}=0.320)$ dengan konstruk komitmen organisasional. Nilai $\mathrm{t}$ - statistic pada hubungan konstruk ini adalah $2.610>1.96$, dan nilai $\mathrm{p}-$ value $0.024<0.05$. Oleh karena itu, hipotesis ketiga yang menyatakan bahwa kecerdasan emosional mempunyai pengaruh yang positif terhadap kepuasan kerja terbukti kebenarannya.

Hasil dari penelitian ini sesuai dengan penelitian - penelitian terdahulu Seyal dan Afzaal (2013), menyatakan dalam penelitiannya bahwa terdapat hubungan pengaruh yang positif dari kecerdasan emosional dengan kepuasan kerja. Sementara Yahyazadeh (2012), menyarankan untuk adanya pelatihan yang di lakukan organisasi bagi para karyawan guna meningkatkan kecerdasan emosional berdasarkan tingkat kepuasan kerja mereka sendiri.

\section{4) Pengaruh Pemberdayaan Karyawan terhadap Kepuasan Kerja}

Konstruk eksogen pemberdayaan karyawan mempunyai pengaruh positif yang signifikan $(\mathrm{O}=0.301)$ dengan konstruk kepuasan kerja. Nilai $\mathrm{t}-$ statistic pada hubungan konstruk ini adalah $2.623>1.96$, dan nilai $\mathrm{p}$ - value $0.009<0.05$. Oleh karena itu, hipotesis keempat yang menyatakan bahwa pemberdayaan karyawan mempunyai pengaruh yang positif terhadap kepuasan kerja terbukti kebenarannya.

Hasil dari penelitian ini sesuai dengan penelitian - penelitian terdahulu Raza et al (2015), menyatakan bahwa ada pengaruh positif yang dilakukan oleh pemberdayaan karyawan terhadap kepuasan kerja seorang karyawan. Surekha dan Singh (2016), mengatakan bahwa organisasi harus menyadari akan peran penting dari pemberdayaan terhadap karyawan karena secara langsung akan dapat meningkatkan kepuasan kerja para karyawan yaitu dengan memberikan karyawan kebebasan dan menjadikan karyawan sebagai kuci dari organisasi.

\section{5) Pengaruh Kepuasan Kerja terhadap Komitmen Organisasional}

Konstruk eksogen kepuasan kerja mempunyai pengaruh positif yang signifikan $(\mathrm{O}$ $=0.227$ ) dengan konstruk komitmen organisasional. Nilai $\mathrm{t}$ - statistic pada hubungan konstruk ini adalah $2.261>1.96$, dan nilai $\mathrm{p}-$ value $0.024<0.05$. Oleh karena itu, hipotesis kelima yang menyatakan bahwa kepuasan kerja mempunyai pengaruh yang positif terhadap komitmen organisasional terbukti kebenarannya.

Hasil dari penelitian ini sesuai dengan penelitian - penelitian terdahulu Azeem dan Akhtar (2014), menyatakan bahwa kepuasan kerja memiliki pengaruh yang positif terhadap komiten organisasi. Ini mengindikasikan bahwa organisasi harus mampu memberikan beberapa hal dan sarana penunjang dalam organisasi yang bisa dilakukan untuk meningkatkan kepuasan kerja para karyawan.

\section{6) Pengaruh Mediasi Kepuasan Kerja dalam Hubungan antara Kecerdasan Emosional} terhadap Komitmen Organisasional

Dari hasil analisis PLS diatas, ditemukan bahwa kecerdasan emosional mempunyai pengaruh positif yang signifikan $(\mathrm{O}=0.260)$ terhadap komitmen organisasional dengan nilai $\mathrm{t}$ - statistic $2.909>1.96$. Kecerdasan emosional mempunyai pengaruh positif yang signifikan terhadap kepuasan kerja $(\mathrm{O}=0.320)$ dengan nilai $\mathrm{t}-$ statistic2.610 $>1.96$. kepuasan kerja mempunyai pengaruh positif yang signifikan $(\mathrm{O}=0.227)$ terhadap komitmen organisasional dengan nilai $\mathrm{t}$ - statistic $2.261>1.96$. Oleh karena itu, hipotesis 
keenam yang menyatakan bahwa kepuasan kerja akan memediasi hubungan antara kecerdasan emosional dan komitmen organisasional terbukti kebenarannya.

Kecerdasan emosional diketahui mempunyai hubungan yang positif terhadap kepuasan kerja (Elias at al 2012, Seyal dan Afzaal 2013, Badawy dan Magdy 2015), dan kepuasan kerja memiliki hubungan pengaruh yang positif terhadap komitmen organisasional (Auda 2016, Azeem dan Akhtar 2014, Aghdasi, Gangai dan Agrawal 2015). Sementara kepuasan kerja dapat memediasi hubungan antara kecerdasan emosional dan komitmen organisasional (Agdhasi, S., dan Ebrahim 2011).

\section{7) Pengaruh Mediasi Kepuasan Kerja dalam Hubungan antara Pemberdayaan Karyawan terhadap Komitmen Organisasional}

Dari hasil analisis PLS diatas, ditemukan bahwa pemberdayaan karyawan mempunyai pengaruh positif yang signifikan $(\mathrm{O}=0.423)$ terhadap komitmen organisasional dengan nilai $\mathrm{t}$ - statistic $4.201>1.96$. pemberdayaan karyawan mempunyai pengaruh positif yang signifikan terhadap kepuasan kerja $(\mathrm{O}=0.301)$ dengan nilai $\mathrm{t}-$ statistic $2.623>1.96$. kepuasan kerja mempunyai pengaruh positif yang signifikan $(\mathrm{O}=$ 0.227 ) terhadap komitmen organisasional dengan nilai $\quad t-$ statistic $2.261>1.96$. Oleh karena itu, hipotesis ketujuh yang menyatakan bahwa kepuasan kerja akan memediasi hubungan antara pemberdayaan karyawan dan komitmen organisasional terbukti kebenarannya.

Kepuasan kerja telah ditemukan memiliki efek mediasi (Gulleryuz et al 2008). Didalam penelitiannya kepuasan kerja dapat memediasi hubungan antara pemberdayaan karyawan, kecerdasan emosional, dan komitmen organisasional. Selain itu penelitian yang dilakukan oleh Goundarzavand dan Kheradmand (2013), menjelaskan tentang adanya hubungan positif antara pemberdayaan karyawan dengan komitmen organisasional.

\section{KESIMPULAN}

Berdasarkan hasil analisis dan pembahasan tentang pengaruh kecerdasan emosional dan pemberdayaan karyawan terhadap komitmen organisasional melalui kepuasan kerja di Dinas Sosial Daerah Istimewa Yogyakarta, maka dapat diberikan beberapa kesimpulan sebagai berikut:

1. Terdapat pengaruh positif yang signifikan antara kecerdasan emosional terhadap komitmen organisasional yang dibuktikan dengan nilai signifikansi dari nilai $\mathrm{t}$ - statistic pada hubungan ini adalah $2.014>1.96$, dan nilai $\mathrm{p}-$ value $0.044<0.05$.

2. Terdapat pengaruh positif yang signifikan antara pemberdayaan karyawan terhadap komitmen organisasional yang dibuktikan dengan nilai signifikansi dari nilai $\mathrm{t}$ - statistic pada hubungan konstruk ini adalah 3.086 $>1.96$, dan nilai $\mathrm{p}$ - value $0.002<0.05$.

3. Terdapat pengaruh positif yang signifikan antara kecerdasan emosional terhadap kepuasan kerja yang dibuktikan dengan nilai signifikansi dari nilai $\mathrm{t}$ - statistic pada hubungan konstruk ini adalh 2.610 $>1.96$, dan nilai $\mathrm{p}$ - value $0.009<0.05$.

4. Terdapat pengaruh positif yang signifikan antara pemberdayaan karyawan terhadap kepuasan kerja yang dibuktikan dengan nilai signifikansi dari nilai $\mathrm{t}$ - statistic pada hubungan konstruk ini adalh $2.623>1.96$, dan nilai $\mathrm{p}$ - value $0.009<0.05$.

5. Terdapat pengaruh positif yang signifikan antara kepuasan kerja terhadap komitmen organisasional yang dibuktikan dengan nilai signifikansi dari nilai $\mathrm{t}$ - statistic pada hubungan konstruk ini adalh 2.261>1.96, dan nilai $\mathrm{p}$ - value $0.024<0.05$.

6. Terdapat pengaruh tidak langsung kecerdasan emosional terhadap komitmen organisasional melalui kepuasan kerja yang dibuktikan dengan nilai signifikansi dari kecerdasan emosional terhadap komitmen organisasional dengan nilai $\mathrm{t}$ - statistic $2.909>1.96$. Kemudian, nilai signifikansi dari kecerdasan emosional terhadap kepuasan kerja dengan nilai $\mathrm{t}$ - statistic 
$2.610>$ 1.96. Sementara, nilai signifikansi dari kepuasan kerja terhadap komitmen organisasional dengan nilai $\mathrm{t}$ - statistic $2.261>1.96$. Maka berdasarkan nilai signifikansi dari masing-masing jalur, dinyatakan bahwa ada pengaruh tidak langsung kecerdasan emosional terhadap komitmen organisasional melalui kepuasan kerja.

Terdapat pengaruh tidak langsung pemberdayaan karyawan terhadap komitmen organisasional melalui kepuasan kerja yang dibuktikan dengan nilai signifikansi dari pemberdayaan karyawan terhadap komitmen organisasional dengan nilai $\mathrm{t}$ - statistic 4.201 > 1.96. Kemudian, nilai signifikansi dari pemberdayaan karyawan terhadap kepuasan kerja dengan nilai $\mathrm{t}$ - statistic $2.623>1.96$. Sementara, nilai signifikansi dari kepuasan kerja terhadap komitmen organisasional dengan nilai $\mathrm{t}$ - statistic $2.261>1.96$. Maka berdasarkan nilai signifikansi dari masing-masing jalur, dinyatakan bahwa ada pengaruh tidak langsung pemberdayaan karyawan terhadap komitmen organisasional melalui kepuasan kerja.

\section{DAFTAR PUSTAKA}

Aghdasi, S., Kiamanesh, A. R., \& Ebrahim, A. N. (2011). Emotional intelligence and organizational commitment: Testing the mediatory role of occupational stress and job satisfaction. Procedia Social and Behavioral Sciences, 29, 1965-1976. https://doi.org/10.1016/j.sbspro.2011.11.447

Alavi, S. Z., Mojtahedzadeh, H., Amin, F., \& Savoji, A. P. (2013). Relationship Between Emotional Intelligence and Organizational Commitment in Iran "s Ramin Thermal Power Plant. Procedia - Social and Behavioral Sciences, 84(1998), 815-819. https://doi.org/10.1016/j.sbspro.2013.06.653.

Allen, N.J., and J.P., Meyer (1990). The Measurement and Antecedents of Affective, Continuance and Normative Commitment to The Organization, Journal of Occupational Psychology, 63, 118

Allen, N.J., and J.P., Meyer (1997). Commitment In The Workplace: Theory, Research, and Applications, California: Sage Publications.

Amstrong, M \& S. Taylor (2014), Armstrongees Handbook of Human Resource Management. 13th Edition. UK: Ashford Colour press Ltd.

Auda, R. M. (2016). Pengaruh Kecerdasan Emosional Terhadap Komitmen Organisasional Melalui Kepuasan Kerja Sebagai Variabel Mediasi pada Bank DKI Kantor Cabang Surabaya, 4(2012), 475-486.

Azeem, S. M., \& Akhtar, N. (2014). Job satisfaction and organizational commitment among Public Sector Employees in Saudi Arabia. International Journal of Business and Social Science, 5(7).

Badawy, T. A. El, \& Magdy, M. M. (2015). Assessing the Impact of Emotional Intelligence on Job Satisfaction: An Empirical Study on Faculty Members with Respect to Gender and Age, 8(3), 67-78. https://doi.org/10.5539/ibr.v8n3p67.

Bogler, R., \& Somech, A. (2004). Influence of teacher empowerment on teacherse organizational commitment, professional commitment and organizational citizenship behavior in schools. Teaching and Teacher Education, 20(3), 277-289. https://doi.org/10.1016/j.tate.2004.02.003

Bohlander, G \& S. Snell (2010). Principles of Human Resource Management. 15thEdition. USA: McGraw Hill Book Co.

Creswell, J. W. (2009). Research Design: Qualitative, Quantitative, and Mixed Methods Approaches. Research design Qualitative quantitative and mixed methods approaches. 
https://doi.org/10.1007/s13398-014-0173-7.2

Elias, A., Officer, P., South, T., \& Bank, I. (2012). Emotional Intelligence and Job Satisfaction : A Correlational study, 37-42.

Gangai, K. N., \& Agrawal, R. (2015). Job satisfaction and organizational commitment: Is it important for employee performance. International Journal of Management and Business Research, 5(4), 269-278. Retrieved fromhttp://www.ijmbr.org/article_7957_00f359f786fbf60d13a40db3cc4b4497.pdf

Ghozali, I. and Latan, H. (2015). Partial Least Square: Konsep, Teknik dan Aplikasi

menggunakan program SmartPLS 3.0 untuk penelitian empiris. 2nd edn. Semarang: Badan Penerbit UNDIP.

Goleman, D. (2003). Emotional Intelligence Untuk Mencapai Puncak Prestasi, Alih Bahasa: Alex Tri K.W, PT. Gramedia Pustaka Utama, Jakarta.

Goleman, D. (2007). Kecerdasan Emosional. Jakarta: Gramedia Pustaka Utama.

Goudarzvandchegini, M., \& Kheradmand, R. (2013). The Relationship between Empowerment and Organizational Commitment, 4(5), 1047-1056.

Güleryüz, G., Güney, S., Aydin, E. M., \& Aşan, Ö. (2008). The mediating effect of job satisfaction between emotional intelligence and organisational commitment of nurses: A questionnaire survey. International Journal of Nursing Studies, 45(11), 1625-1635. https://doi.org/10.1016/j.ijnurstu.2008.02.004

Gibson, James L., Donnelly Jr, James H., Ivancevich, John M., Konopaske, Robert (2012). Organizationa Behavior, Structure, Processes, Fourteenth Edition (International Edition).1221 Avenue of The Americas, New York, NY 10020: McGraw-Hill.

Hanaysha, J. (2016). Examining the Effects of Employee Empowerment, Teamwork, and Employee Training on Organizational Commitment. Procedia - Social and Behavioral Sciences, 229, 298-306. https://doi.org/10.1016/j.sbspro.2016.07.140

Herzberg, F., Mausner, B., \& Snyderman, B., (1959), The Motivation to Work. Published by Wiley.

Jafari, V., Moradi, M. ali, \& Ahanchi, M. (2013). An examination of the relationship between empowerment and organizational commitment ( Case study Kurdistan province electric staff ). Interdisciplinary Journal of Contemporary Research in Business, 4(12), 860-868.

Jogiyanto, H., (2011). Metodologi Penelitian Bisnis: Salah Kaprah dan Pengalaman-pengalaman. BPFE. Yogyakarta.

Karambut, C. a. (2012). Analisis Pengaruh Kecerdasan Emosional, Stres Kerja dan Kepuasan Kerja terhadap Komitmen organisasionalonal (Studi pada Perawat Unit Rawat Inap RS Panti Waluya Malang). Jurnal Aplikasi Manajemen, 10(3).

Karim, F., \& Rehman, O. (2012). Impact of job satisfaction, perceived organizational justice and employee empowerment on organizational commitment in semi-government organizations of Pakistan. Journal of Business Studies Quarterly, 3(4), 92-104. https://doi.org/10.1017/CBO9781107415324.004

Khan, S. (1997). “The Key to Being a Leader Company: Empowerment”. Journal for Quality and Participatio. 44-50.

Luthans, F (2006). Organizational Behavior: An Evidence Based Approach. 12th Edition. New York: The McGraw Hill Companies, Inc.

Mathis, R. \& J, Jackson, (2011), Human Resources Management. 13thEdition, USA: South Western 
Cengage Learning.

Mulyadi., (2007), Sistem Perencanaan dan Pengendalian Manajemen. Salemba. Empat. Jakarta.

Palupi, M. \& Tjahjono, H.K. (2016). A Model of Religiousity and Organizational Justice: The impact on Commitment and Dysfunctional behavior. Proceedings of the 27th Ibima Conference

Parameswari, A.A.A., dan Rahyuda, A.G., (2014), Pengaruh Pemberdayaan Karyawan Terhadap Persepsi Keadilan Organisasi Dan Komitmen Organisasi (Studi Kasus Pada Badan Lingkungan Hidup (Blh) Kabupaten Gianyar, Bali), E-Jurnal Manajemen Universitas Udayana, Vol. 3, No.12.

Porter, L.W., Mowday, R.T. and Boulian, P.V., (1974), "Organizational Commitment, Job Satisfaction and Turnover Among Psychiatric Technicians”. Journal of Applied Psychology. October, pp. 603-609.

Raza, H., Mahmood, J., Owais, M., \& Raza, A. (2015). Impact of Employee Empowerment on Job Satisfaction of Employees in Corporate Banking Sector Employees of Pakistan. J. Appl. Environ. Biol. Sci, 5(2), 1-7.

Rivai, V., (2009), Manajemen Sumber Daya Manusia Untuk Perusahaan Dari Teori ke Praktik. Jakarta: Raja Grafindo Persada.

Robbins, S. P, et al (2006). Perilaku Organisasi (terj. Benjamin M), Edisi 10, PT Indeks : Jakarta

Sarawati, S., \& Johar, H. (2014). The impact of emotional intelligence on organizational commitment through self-esteem of employee in public sector Ishak Mad Shah Faculty of Management. The Business \& Management Review, 4(3), 1-12.

Seyal, A. H., \& Afzaal, T. (2013). An Investigation of Relationship among Emotional Intelligence, Organizational Commitment and Job Satisfaction: Evidence from Academics in Brunei Darussalam. International Business Research, 6(3), 217-228. https://doi.org/10.5539/ibr.v6n3p217

Shafiq, M., \& Rana, R. A. (2016). Relationship of Emotional Intelligence to Organizational Commitment of College Teachers in Pakistan. Eurasian Journal of Educational Research, 16(62), 1-14. https://doi.org/10.14689/ejer.2016.62.1

Snell, S. and Bohlander, G. (2013). Managing Human Resources. 16th edn. South Western: Cengange Learning.

Sobhani, H. (2016). Investigating the Impact of Employee " s Empowerment on Their Job Satisfaction ( Case Study : Tejarat Bank, West Azerbaijan Province , Iran ), 1452-1459.

Spector, P (2000). Industrial and Organizational Psychology: Research and Practice. 5thEdition. USA: John Wiley \& Sons, Inc.

Spector, P.E (1997). Industrial and Organizational Psychology Research and Practice, Second edition, New York: Jhon Wily \& Sons, Inc

Spreitzer, G. M. (1995). „Psychological Empowerment in the Workplace: Dimensions, measurement, and validation ${ }^{\mathrm{ee}}$, Academy of Management Journal, 38(5), pp. 1442-1465.

Surekha, R., \& Singh, V. (2016). Employee Empowerment and Job Satisfaction: An Empirical study in IT Industry. IOSR Journal of Humanities And Social Science, 21(12), 23-29. https://doi.org/10.9790/0837-2110122329

Tjahjono, H.K. (2008). Studi Literatur Pengaruh Keadilan Distributif dan Keadilan Prosedural pada konsekuensinya dengan teknik Meta Analisis. Jurnal Psikologi Universitas Gadjah Mada, 35(1): $21-40$ 
Tjahjono, H.K, Palupi, M. \& Dirgahayu, P. (2015). Career Perception at the Republic Indonesian Police Organization Impact of Distributive Fairness, Procedural Fairness and Career Satisfaction on Affective Commitement. International Journal of Administrative Science \& Organization, 22(2): 130-135.

Yahyazadeh-jeloudar, S. (2012). Teachers " Emotional Intelligence and Its Relationship with Job Satisfaction, 1(1), 4-9. 